\section{Transcranial doppler sonography: nitrous oxide and cerebral blood flow velocity in children}

Jeffrey E. Leon MD, Bruno Bissonnette MD
To determine the effect of nitrous oxide $\left(\mathrm{N}_{2} \mathrm{O}\right)$ on cerebral blood flow velocity (CBFV) and cerebrovascular resistance index $(R I+)$ in children, ten ASA physical status I or II patients aged one to eight years old, scheduled for urological procedures, were studied. Anaesthesia was induced with thiopentone 2 $\mathrm{mg} \cdot \mathrm{kg}^{-1}$, fentanyl $5 \mu \mathrm{g} \cdot \mathrm{kg}^{-1}$ and diazepam $0.3 \mathrm{mg} \cdot \mathrm{kg}^{-1}$. Muscular relaxation was ensured by using vecuronium 0.1 $m g \cdot \mathrm{kg}^{-1}$. After tracheal intubation, anaesthesia was randomly assigned to either a mixture of air in oxygen $\left(\mathrm{N}_{2} / \mathrm{O}_{2}\right)$ or $70 \%$ $\mathrm{N}_{2} \mathrm{O}$ in oxygen $\left(\mathrm{N}_{2} \mathrm{OlO}_{2}\right)$ producing an $\mathrm{FlO}_{2}$ of $30 \%$. Three sets of measurements of CBFV and RI+ were made with both gas mixtures. The CBFV and RI+ were measured in the middle cerebral artery (MCA) with a transcranial Doppler monitor. Measurements were made while using the inirial gas mixture, then the second gas mixture was administered, and finally, the patient again was given the initial gas mixture. A continuous caudal epidural or lumbar epidural block was performed before skin incision. Neuromuscular blockade was maintained with vecuronium $0.05 \mathrm{mg} \cdot \mathrm{kg}^{-1}$. Temperature, heart rate, end-tidal $\mathrm{CO}_{2}$, arterial oxygen saturation, haematocrit and arterial blood pressure were maintained constant. Ventilation was adjusted to

\section{Key words}

ANAESTHESIA: paediatric;

ANAESTHETICS, VOLATILE: nitrous oxide;

BRAIN: blood flow;

MEASUREMENT TECHNIQUES: transcranial Doppler

From the Department of Anaesthesia, The Hospital for Sick Children, University of Toronto, Toronto, Ontario, Canada M5G 1X8. Presented in part at the 47th annual meeting of the Canadian Anaesthetists' Society, Vancouver, British Columbia, Canada, June 15-19, 1990.

Address correspondence to: Dr. Bruno Bissonnettc, Director of Neuroanaesthesia, Department of Anaesthesia, The Hospital for Sick Children, 555 University Avenue, Toronto, Ontario, Canada M5G 1 X8.

Accepted for publication 17th June, 1991. achieve normocapnia. The $\mathrm{CBFV}$ increased when 70\% $\mathrm{N}_{2} / \mathrm{O}_{2}$ was replaced by $70 \% \mathrm{~N}_{2} \mathrm{O}_{2} \mathrm{O}_{2}(P<0.05)$ while the $\mathrm{CBFV}$ decreased when $70 \% \mathrm{~N}_{2} \mathrm{O}_{2}$ was readministered $(P<0.05)$. Likewise, the $\mathrm{CBFV}$ decreased when $70 \% \mathrm{~N}_{2} \mathrm{OlO}_{2}$ was replaced by $70 \% \mathrm{~N}_{2} \mathrm{O}_{2}(P<0.05)$ while the $\mathrm{CBFV}$ increased when $70 \%$ $\mathrm{N}_{2} \mathrm{O}_{2} \mathrm{O}_{2}$ was readministered $(P<0.05)$. The $\mathrm{RI}+$, heart rate and blood pressure showed no change at any time during the study. These data indicate that $\mathrm{N}_{2} \mathrm{O}$, in clinical dosage, increases the $C B F V$ in healthy children while the $R I+$ remains unchanged. These effects are probably due to the direct effect of $\mathrm{N}_{2} \mathrm{O}$ on cerebral mitochondrial activity.

Afin de déterminer l' effet de l'oxide nitreux $\left(\mathrm{N}_{2} \mathrm{O}\right)$ sur la vélocité du débit sanguin cérébral (CBFV) et sur l'index des résistances cérébrovasculaire $(R I+)$, dix enfants agés de deux à huit ans et ayant un état physique ASA I ou ll et cédulés pour une chirurgie urologique ont été étudies. L'induction de l'anesthésie était accomplie avec du thiopentone $2 \mathrm{mg} \cdot \mathrm{kg}^{-1}$, fentanyl $5 \mu \mathrm{g} \cdot \mathrm{kg}^{-1}$, et diazepam $0,3 \mathrm{mg} \cdot \mathrm{kg}^{-1}$. La relaxation musculaire était assuré par du vécuronium $0,1 \mathrm{mg} \cdot \mathrm{kg}^{-1}$. Après intubation endotrachéale, la maintenance anesthésique était aléatoirement choisi pout être débuté soit par l'utilisation d'air dans de l'oxgène $\left(\mathrm{N}_{2} / \mathrm{O}_{2}\right)$ ou $70 \% \mathrm{~N}_{2} \mathrm{O}$ dans de l'oxygène $\left(\mathrm{N}_{2} \mathrm{O}_{2} \mathrm{O}_{2}\right)$ pour une $\mathrm{FlO}_{2}$ de 30\%. La CBFV et la $\mathrm{RI}+$ était obtenue par mesure de l'artère cérébrale moyenne (MCA) avec une sonde Doppler transcranienne Doppler. La CBFV et la RI+ ont été mesurés pour chaque mélange utilisé. Après avoir obtenus $C B F V$ et $R I+$ avec le mélange initial, l'autre mélange gazeux était administré et finalement, le patient reçevait de nouveau le mélange initial. One analgésie régionale lombaire ou caudale épidurale était performée avant le début de l'intervention chirurgicale. La température, le rythme cardinque, la saturation en oxygène et la pression artérielle systolique étaient maintenu constant. La ventilation controllée par mode intermittent de pression positive était ajustée pour assurer la normocap. nie. La CBFV a augmentée de $70 \%$ lorsque $\mathrm{N}_{2} \mathrm{OlO}_{2}$ était remplacé par le mélange $\mathrm{N}_{2} \mathrm{O}_{2}(P<0,05)$ pendant que la CBFV a diminuée de $70 \%$ lorsque $\mathrm{N}_{2} \mathrm{O}_{2}$ etait readministré ( $P$ $<0,05$ ). Par ailleurs, la CBFV a diminuée de $70 \%$ lorsque la $\mathrm{N}_{2} \mathrm{O} / \mathrm{O}_{2}$ était remplacé par $\mathrm{N}_{2} / \mathrm{O}_{2}(P<0,05)$ pendant que la 
CBFV a augmentée de $70 \%$ lorsque $\mathrm{N}_{2} \mathrm{O}_{2} \mathrm{O}_{2}$ était réadministré $(P<0.05) . L a R I+$ ainsi que le rythme cardiaque et la pression artérielle n'ont en aucun temps changés. Ces informations indique que $\mathrm{N}_{2} \mathrm{O}$ en dose clinique augmente la $\mathrm{CBFV}$ chez les enfants anesthésiés pendant que la $R I+$ demeure inchangée. Ceci est une indication très probable d'un effet direct du $\mathrm{N}_{2} \mathrm{O}$ sur l'activité mitochondrial cérébrale.

Despite substantial investigation, the effect of nitrous oxide $\left(\mathrm{N}_{2} \mathrm{O}\right)$ on cerebral circulation remains controversial.' Pelligrino et al. showed an increase in cerebral blood flow (CBF) and cerebral oxygen consumption $\left(\mathrm{CMRO}_{2}\right)$ in goats given $70 \% \mathrm{~N}_{2} \mathrm{O} .{ }^{2}$ Wollman et al. showed an increase in CBF and a decrease in $\mathrm{CMRO}_{2}$ in adults given $70 \% \mathrm{~N}_{2} \mathrm{O} .{ }^{3}$ Theye and Michenfelder showed an $11 \%$ increase in $\mathrm{CMRO}_{2}$ in dogs given $\mathrm{N}_{2} \mathrm{O} .{ }^{4}$ Carlsson et al. showed no change in $\mathrm{CMRO}_{2}$ in rats given $70 \%$ $\mathrm{N}_{2} \mathrm{O}^{5}$ Sakabe $e t$ al. found an increase in CBF in adults given $60 \% \mathrm{~N}_{2} \mathrm{O}$, whereas in dogs given $60 \% \mathrm{~N}_{2} \mathrm{O}$ they found an increase in CBF and $\mathrm{CMRO}_{2}$ and no change in cerebrovascular resistance. ${ }^{6,7}$ Though the studies showed that $\mathrm{N}_{2} \mathrm{O}$ caused an increase in CBF, many of the experiments were complicated by concurrent usage of halothane or isoflurane. ${ }^{8}$ As a result, there is no consensus on the true effect of $\mathrm{N}_{2} \mathrm{O}$ on the cerebral blood flow and cerebrovascular resistance.

Hitherto, the measurement of CBF has been accomplished with invasive technology such as radiolabelled isotopes or cerebral angiography. Such methods are unsuitable for routine investigation in children. Recent advances in the field of ultrasound have made it possible to estimate CBF noninvasively. Transcranial Doppler sonography (TCD), a non-invasive technique described by Aaslid (1982) may be used to measure the velocity of blood flowing in the large basal cerebral arteries. ${ }^{9-11}$ The adaptation of a $2 \mathrm{MHz}$ Doppler allows insonation of intracerebral arteries through thin bone in older children and adults. Previously, intracranial arteries were inaccessible to Doppler-shifted ultrasound measurements except in neonates, infants, and young children with open fontanelles.

Due to the widespread use of $\mathrm{N}_{2} \mathrm{O}$ in neurosurgical anaesthesia, it is important to know the cerebrovascular responses to $\mathrm{N}_{2} \mathrm{O}$ in anaesthetized children. This study was undertaken using TCD to evaluate the effect of $\mathrm{N}_{2} \mathrm{O}$ on cerebral blood flow velocity (CBFV) and cerebrovascular resistance index $(\mathrm{RI}+)$ in such patients.

\section{Methods}

\section{Practical procedure}

Following approval from our Human Subjects Review
Committee, written, informed consent was obtained from the parents of ten healthy ASA physical status I or II children, aged from one to eight years old, scheduled for elective urological surgery. All children were fasting and unpremedicated. Patients with cardiac or neurological disease or patients with contraindication to regional anaesthesia were excluded. All patients were supine and horizontal throughout the study.

Anaesthesia was induced with intravenous thiopentone $2 \mathrm{mg} \cdot \mathrm{kg}^{-1}$, fentanyl $5 \mu \mathrm{g} \cdot \mathrm{kg}^{-1}$, diazepam $0.3 \mathrm{mg} \cdot \mathrm{kg}^{-1}$, and vecuronium $0.1 \mathrm{mg} \cdot \mathrm{kg}^{-1}$. After tracheal intubation intermittent positive pressure ventilation was adjusted to achieve a $\mathrm{PETCO}_{2}$ of $40 \mathrm{mmHg}$. Positive end-expiratory pressure was avoided. Fresh gas flow was maintained constant throughout the study to avoid changes in intrathoracic pressure. In a random fashion, anaesthesia was maintained with either a mixture of air in oxygen $\left(\mathrm{N}_{2} / \mathrm{O}_{2}\right)$ or $70 \% \mathrm{~N}_{2} \mathrm{O} / \mathrm{O}_{2}$ with an $\mathrm{FlO}_{2}$ of $30 \%$. Muscle relaxation was monitored by peripheral nerve stimulator and maintained with vecuronium $0.05 \mathrm{mg} \cdot \mathrm{kg}^{-1}$. A continuous caudal epidural or lumbar epidural block using $0.25 \%$ bupivacaine without epinephrine was administered to all patients before incision. Normothermia was maintained using a humidity and moisture exchanger (GibeckDryden Corporation, Indianapolis, Indiana, USA) ${ }^{12,13}$ and a warming blanket. ${ }^{14}$ Lactated Ringer's solution (5 $\mathrm{ml} \cdot \mathrm{kg}^{-}$) was administered over the initial $15 \mathrm{~min}$ to compensate for preoperative fasting. All patients received $2 \mathrm{ml} \cdot \mathrm{kg}^{-1} \cdot \mathrm{hr}^{-1}$ lactated Ringer's solution as maintenance fluid and additional fluid was given as needed to replace surgical losses. Systolic arterial blood pressure was measured by sphygmomanometer and Doppler ultrasonic transducer, ${ }^{15}$ heart rate, $\mathrm{ErCO}_{2}$, arterial oxygen saturation, and inspired $\mathrm{O}_{2}$ fractions were maintained at constant levels throughout the study. The end-tidal concentrations of $\mathrm{N}_{2} \mathrm{O}$ and $\mathrm{CO}_{2}$ were measured from the distal end of the tracheal tube and analyzed with a calibrated Puritan-Bennett Datex 254 airway gas monitor (Datex Instrumentation Corporation, Helsinki, Finland). ${ }^{16}$ The gas monitor was calibrated using a reference gas mixture before each use.

Fifteen-minute periods were allowed between $\mathrm{N}_{2} / \mathrm{O}_{2}$ or $\mathrm{N}_{2} \mathrm{O} / \mathrm{O}_{2}$ changes to achieve steady-state conditions. After each period, the investigator (BB) who was unable to see the TCD screen, recorded three consecutive measurements of CBFV and $\mathrm{RI}+$ in the MCA at one-minute intervals. Following these measurements, the patients received the alternate gas mixture and a further three measurements of CBFV and RI+ were recorded after the equilibration period. Finally, the patients received the original gas mixture and three measurements of CBFV and RI+ were again recorded. The CBFV and RI+ were recorded with a TCD (Transpect TCD, Medasonics, 
TABLE Data summary

\begin{tabular}{|c|c|c|c|c|c|c|c|c|}
\hline & $\mathrm{N}_{2} \mathrm{O} / \mathrm{O}_{2}$ & $\mathrm{~N}_{2} / \mathrm{O}_{2}$ & $\mathrm{~N}_{2} \mathrm{O} \mathrm{O}_{2}$ & $\mathrm{~N}_{2} / \mathrm{O}_{2}$ & $\mathrm{~N}_{2} \mathrm{OlO}_{2}$ & $\mathrm{~N}_{2} / \mathrm{O}_{2}$ & $P^{a}$ & $p^{b}$ \\
\hline HR (beats/min ${ }^{-1}$ ) & $81 \pm 14$ & $81 \pm 16$ & $80 \pm 16$ & $83 \pm 7$ & $81 \pm 6$ & $82 \pm 7$ & NS & NS \\
\hline $\mathrm{SABP}(\mathrm{mmHg})$ & $87 \pm 13$ & $88 \pm 14$ & $86 \pm 12$ & $98 \pm 15$ & $98 \pm 15$ & $99 \pm 16$ & NS & NS \\
\hline $\mathrm{ETCO}_{2}(\mathrm{mmHg})$ & $40 \pm 2$ & $39 \pm 2$ & $39 \pm 1$ & $39 \pm 3$ & $38 \pm 2$ & $38 \pm 3$ & NS & NS \\
\hline \multirow[t]{2}{*}{$\operatorname{Temp}\left({ }^{\circ} \mathrm{C}\right)$} & 36.8 & 36.7 & 36.7 & 36.8 & 36.8 & 36.7 & NS & NS \\
\hline & \pm 0.2 & \pm 0.2 & \pm 0.1 & \pm 0.1 & \pm 0.1 & +0.2 & NS & NS \\
\hline $\mathrm{AP}\left(\mathrm{cmH}_{2} \mathrm{O}\right)$ & $21 \pm 3$ & $20 \pm 2$ & $20 \pm 3$ & $22 \pm 2$ & $21 \pm 3$ & $20 \pm 3$ & NS & NS \\
\hline $\mathrm{SaO}_{2}(\%)$ & $98 \pm 3$ & $99 \pm 2$ & $99 \pm 2$ & $98 \pm 3$ & $97 \pm 3$ & $99 \pm 1$ & NS & NS \\
\hline \multirow[t]{2}{*}{$\operatorname{CBFV}\left(\mathrm{cm} / \mathrm{sec}^{-1}\right)$} & 108,4 & 101.4 & 109.1 & 97.9 & 107.9 & 96.9 & $<.05$ & $<.05$ \\
\hline & \pm 23.4 & \pm 23.0 & \pm 21.9 & \pm 15.18 & \pm 27.3 & \pm 18.2 & & \\
\hline \multirow[t]{2}{*}{ RI+ } & 0.66 & 0.66 & 0.68 & 0.67 & 0.67 & 0.64 & NS & NS \\
\hline & \pm .05 & \pm .03 & \pm .06 & \pm .06 & \pm .10 & \pm 0.06 & NS & NS \\
\hline
\end{tabular}

All values are mean (SD), $n=5 /$ group.

Abbreviations: HR, heart rate; SABP, systolic arterial blood pressure; $\mathrm{ETCO}_{2}$, end-tidal $\mathrm{CO}_{2}$; TEMP, temperature; AP, airway pressure; $\mathrm{SaO}_{2}$, arterial oxygen saturation; CBFV, cerebral blood flow velocity; $\mathrm{RI}+$, cerebrovascular resistance.

${ }^{a} P$ Values by one-way analysis of variance and Student Newman-Keuls for multiple comparisons within $\mathrm{N}_{2} \mathrm{O} / \mathrm{O}_{2}-\mathrm{N}_{2} / \mathrm{O}_{2}-\mathrm{N}_{2} \mathrm{O} / \mathrm{O}_{2}$.

${ }^{b} P$ Values by repeated-measures of variance and Student Newman-Keuls for multiple comparisons within $\mathrm{N}_{2} / \mathrm{O}_{2}-\mathrm{N}_{2} \mathrm{O} / \mathrm{O}_{2}$

$-\mathrm{N}_{2} / \mathrm{O}_{2}$

Fremont, CA) the specifications of which and the methodology of recording the MCA has been previously described. ${ }^{17}$ Systolic arterial blood pressure, heart rate, $\mathrm{ETCO}_{2}$, arterial oxygen saturation, temperature, and $\mathrm{FIO}_{2}$ were recorded with each steady-state measurement.

\section{Statistical analysis}

The mean \pm standard deviation (SD) for age and weight were determined. The analysis of each TCD file was done by an investigator (BB) who was unaware of the gas mixture sequence at which each file was recorded. Each file represents eight seconds of recording from which an average from three cycles was obtained to evaluate the CBFV and to calculate the RI+. Based on a previous human adult study ${ }^{8}$ and for a power analysis of 0.80 , an alpha value of 0.05 and a beta value of 0.20 , the calculated number of patients needed to reject the null hypothesis was five per group. Repeated-measures analysis of variance and the Student Newman-Keuls test for multiple comparisons were used to determine the relationship within group $\left(70 \% \mathrm{~N}_{2} \mathrm{O} / \mathrm{O}_{2}\right.$ or $\left.\mathrm{N}_{2} / \mathrm{O}_{2}\right)$ and CBFV, $\mathrm{RI}+$, heart rate, systolic arterial blood pressure, $\mathrm{ETCO}_{2}$, temperature and arterial oxygen saturation. A $P<0.05$ was considered statistically significant.

\section{Results}

The mean $\pm S D$ age and weight of the ten children were $41.7 \pm 27.9 \mathrm{mo}$ and $15.5 \pm 5.9 \mathrm{~kg}$, respectively. Heart rate, systolic arterial blood pressure, $\mathrm{ETCO}_{2}$, temperature, $\mathrm{FlO}_{2}$, and arterial $\mathrm{O}_{2}$ saturation did not change during the study period (Table). Doppler recordings of the CBFV in the MCA and calculations of RI+ values were completed in all children for $70 \% \mathrm{~N}_{2} \mathrm{O} / \mathrm{O}_{2}$ and for $\mathrm{N}_{2} / \mathrm{O}_{2}$ (Table).

The CBFV increased $9.9 \%$ when $70 \% \quad \mathrm{~N}_{2} / \mathrm{O}_{2}$ was replaced by $70 \% \mathrm{~N}_{2} \mathrm{O} / \mathrm{O}_{2}(P<0.05)$. When $70 \% \mathrm{~N}_{2} / \mathrm{O}_{2}$ was readministered, $\mathrm{CBFV}$ returned to the initial value (Figure). Conversely, we found that the CBFV decreased $8.7 \%$ when $70 \% \mathrm{~N}_{2} \mathrm{O} / \mathrm{O}_{2}$ was replaced by $70 \% \mathrm{~N}_{2} / \mathrm{O}_{2}(P$ $<0.05$ ). When $70 \% \mathrm{~N}_{2} \mathrm{O} / \mathrm{O}_{2}$ was readministered, $\mathrm{CBFV}$ returned to initial value (Figure). The $\mathrm{RI}+$ did not change during any of the measurements. There were no complications from the use of the TCD in this study.

\section{Discussion}

We showed that $70 \% \mathrm{~N}_{2} \mathrm{O}$ increased $\mathrm{CBFV}$ independently of any significant changes in cerebrovascular resistance index, systolic arterial blood pressure or heart rate. These data indicate that $\mathrm{N}_{2} \mathrm{O}$ in clinical doses increases the CBFV in healthy children while $\mathrm{RI}+$ remains unchanged. It is possible that $\mathrm{N}_{2} \mathrm{O}$ may have a direct effect on the neurotransmitter activity of the vasomotor centre or an effect on mitochondrial cerebral metabolic activity with a resultant coupled increase in CBF without any sympathoadrenal responses.

Pelligrino et al. reported that in goats, $\mathrm{N}_{2} \mathrm{O} / \mathrm{O}_{2}$ increased $\mathrm{CBF}$ with a parallel increase in $\mathrm{CMRO}_{2}$ without any alterations in arterial blood pressure and heart rate. It was hypothesized that these results were attributed to direct effects of $\mathrm{N}_{2} \mathrm{O}$ on cerebral metabolism and cerebral blood flow. ${ }^{2}$ The authors measured serum catecholamine levels and high energy phosphate bonds (phosphocreatine, ATP, ADP, AMP, glucose-6-phosphate, fructose6-phosphate lactate, and pyruvate) and showed that there 


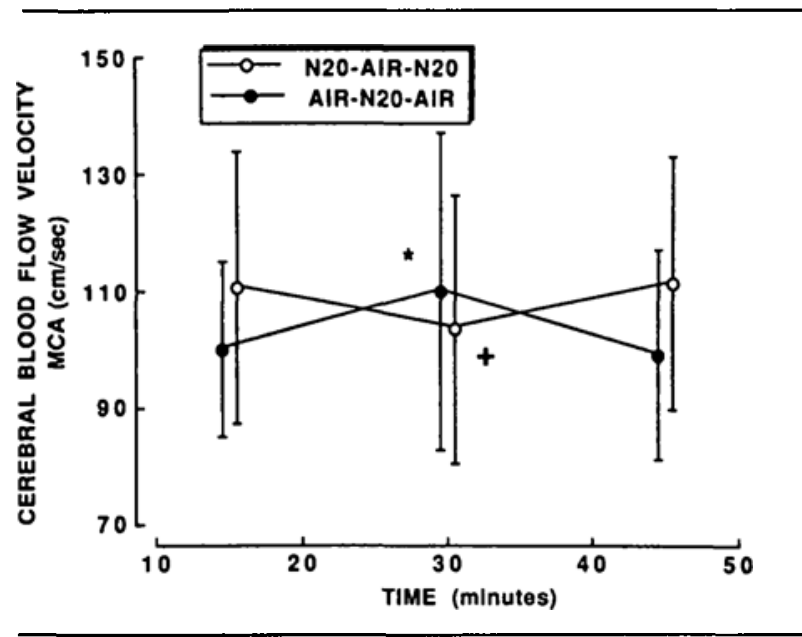

FIGURE Cerebral blood flow velocity (CBFV) recorded during gas mixture alternation between $\mathrm{N}_{2} \mathrm{O} / \mathrm{O}_{2}$ and air $/ \mathrm{O}_{2}\left(\mathrm{~N}_{2} / \mathrm{O}_{2}\right)$. Values are reported as mean \pm SD. ${ }^{*} P<0.05$ compared with $\mathrm{N}_{2} \mathrm{O} / \mathrm{O}_{2}$ before and after $\mathrm{N}_{2} / \mathrm{O}_{2} .+P<0.05$ compared with $\mathrm{N}_{2} / \mathrm{O}_{2}$ before and after $\mathrm{N}_{2} / \mathrm{O}_{2}$.

was a decrease in serum catecholamines and no evidence of an increase in glycolytic intermediates. However, this did not eliminate the possible effect of $\mathrm{N}_{2} \mathrm{O}$ on the brain redox function and cellular energy demand. Rosenthal et al. reported that in rats an increased oxidation of cytochrome $\mathrm{a}, \mathrm{a}_{3}$, occurs during $\mathrm{N}_{2} \mathrm{O}$ anaesthesia, suggesting an increased energy demand. ${ }^{18}$ Pelligrino et al. using a goat cerebrocortical mitochondrial preparation in vitro, observed that the increased $\mathrm{O}_{2}$ utilization during exposure to $\mathrm{N}_{2} \mathrm{O}$ may be due at least partly to a direct effect of $\mathrm{N}_{2} \mathrm{O}$ on mitochondrial respiration. ${ }^{2}$ Under normal conditions, the brain is dependent upon a continuous supply of blood in order to obtain a continuous flow of $\mathrm{O}_{2}$ as well as glucose to the cells. ${ }^{19}$ Any alterations in the electron transport through the mitochondrial respiratory chain may result in a modification in $\mathrm{O}_{2}$ utilization and a change in cerebral blood flow. ${ }^{19}$ It is permissible to speculate that $\mathrm{N}_{2} \mathrm{O}$, through a direct cellular effect, affects the electron transport of the inner membrane of the mitochodrion and decreased $\mathrm{O}_{2}$ utilization by the respiratory chain, thus increasing cerebral blood flow. In this study measurement of the CBFV with both $\mathrm{N}_{2} \mathrm{O} / \mathrm{O}_{2}$ and $\mathrm{N}_{2} / \mathrm{O}_{2}$ demonstrated an increase in CBFV with $\mathrm{N}_{2} \mathrm{O} / \mathrm{O}_{2}$. There was no change in $\mathrm{RI}+$. This lack of change in the $\mathrm{RI}+$ suggests a coupling of the $\mathrm{CBF}-\mathrm{CMRO}_{2}$ match. Todd $e t$ al. showed that $\mathrm{N}_{2} \mathrm{O}$ causes a consistent increase in EEG frequency and a decrease in amplitude compared with $\mathrm{N}_{2} \cdot{ }^{20}$ Vernheit $e t$ al. reported that $\mathrm{N}_{2} \mathrm{O}$ causes a $70 \%$ increase in $\mathrm{CMRO}_{2}$ by its stimulating effect on the electrocortical activity as a secondary effect on brainstem reticular centers. ${ }^{21}$ Although we did not measure $\mathrm{CMRO}_{2}$ or record EEG in this series of children, this cerebral excitatory state does not appear to be related to sympathetic activity. Several studies have reported that $\mathrm{N}_{2} \mathrm{O}$ can increase sympathetic activity ${ }^{22.23}$ by an action originating from the suprapontine levels. ${ }^{24}$ This would suggest that the possible increase in cerebral blood flow velocity was the result of sympathoadrenal stimulation. This study did not show any sign of increase in arterial blood pressure and/or heart rate while CBFV increased.

Kaieda et al. reported that no increase in $\mathrm{CMRO}_{2}$ occurred due to $\mathrm{N}_{2} \mathrm{O}$ anaesthesia. He suggested that the change in $\mathrm{CBF}$ with $\mathrm{N}_{2} \mathrm{O}$ was not mediated by metabolic changes, but implied that $\mathrm{N}_{2} \mathrm{O}$ may act as a direct cerebral vasodilator. ${ }^{25}$ If our observations had shown that at a constant arterial blood pressure and heart rate, the effect of $\mathrm{N}_{2} \mathrm{O}$ (expressed by a decrease in $\mathrm{RI}+$ ) is to produce cerebral vasodilatation, we would have expected a decrease in CBFV. Since we found an increase in CBFV with no change in RI+ our study cannot support the findings of Kaieda. ${ }^{25}$

Our methodology may be criticized insofar as we deepened anaesthesia by adding $70 \% \mathrm{~N}_{2} \mathrm{O}$. The magnitude of this effect varies considerably from study to study, but a recurring pattern suggests that the production of deeper anaesthesia may reduce the increase in $\mathrm{CBF}{ }^{8}$ Cerebral blood flow is directly proportional to the perfusion pressure gradient across the cerebral circulation in the brain and if the systolic arterial blood pressure decreases as the concentration of $\mathrm{N}_{2} \mathrm{O}$ increases and anaesthesia deepens, we would expect CBFV to decrease. No changes in systolic arterial blood pressure or heart rate were found at any time during the study, but CBFV increased consistently when $\mathrm{N}_{2} \mathrm{O} / \mathrm{O}_{2}$ was substituted for $\mathrm{N}_{2} / \mathrm{O}_{2}$.

To reduce the surgical nociceptive stimulus and the sympathetic response to the incision and to limit the known effect of any changes of the arterial blood pressure and heart rate on the cerebral blood flow ${ }^{26-29}$ we performed a lumbar epidural or caudal block. Dohi et al. confirmed the clinical impression that children under six years old do not experience any change in arterial blood pressure and heart rate following spinal anaesthesia. ${ }^{30}$ Delleur et al. reported the effects of epidural anaesthesia on 76 infants and children less than eight years old. ${ }^{31}$ In no case did any change in arterial blood pressure or heart rate occur. None of the patients in our study showed any changes in systolic arterial blood pressure or heart rate after administration of the regional anaesthesia.

The equilibration time constant for nitrous oxide in the grey matter of the brain is $0.47 \mathrm{~min} .{ }^{32}$ In this study, when the airway gas monitor reached a stable $70 \%$ reading for the $\mathrm{N}_{2} \mathrm{O} / \mathrm{O}_{2}$ group or a $0 \%$ reading indicating that $\mathrm{N}_{2} \mathrm{O}$ 
had been completely eliminated for the $\mathrm{N}_{2} / \mathrm{O}_{2}$ group, we delayed measurements for a further $15 \mathrm{~min}$ to ensure steady-state conditions within the brain. If the 15-min equilibration periods had been inadequate, then CBFV would have changed between the first and third measurements in an individual patient for any single set of conditions. However, the data showed a coefficient of variation of $\leq 7 \%$ between the first and third recordings for any set of measurements.

Intrathoracic pressure affects cerebral perfusion pressure by its direct effect on venous return and therefore cerebral venous pressure. To maintain a constant mean intrathoracic pressure during the study we kept the respiratory rate and tidal volume constant, maintaining a $\mathrm{PETCO}_{2}$ of about $40 \mathrm{mmHg}$. The arterial $\mathrm{PCO}_{2}$ was estimated by measuring the $\mathrm{PETCO}_{2}$ at the distal end of the endotracheal tube. Previous studies have shown that both single-breath and continuous distal PETCO 2 closely approximates $\mathrm{PaCO}_{2}$ in healthy infants and children. ${ }^{16,33}$

There are several methodological considerations that merit comment. The cerebral blood flow velocity and cerebrovascular resistance were measured by transcranial Doppler and several assumptions underly the relationship between CBFV and CBF. ${ }^{10,17}$ Moreover, other potential pitfalls in measurements which could account for large variations in measurement have been discussed in a previous paper. ${ }^{17}$

In summary we have shown that $\mathrm{N}_{2} \mathrm{O}$ increases CBFV and although the mechanism is not known it is speculated that $\mathrm{N}_{2} \mathrm{O}$ causes an increase in CBFV by a coupling of CBF-CMRO ${ }_{2}$ probably because of a direct effect of $\mathrm{N}_{2} \mathrm{O}$ on cerebral mitochondrial activity. These findings are consistent with previous investigations on the effect of $\mathrm{N}_{2} \mathrm{O}$ on CBF. The clinical implications remains unclear. ${ }^{20}$ Before applying this observation to clinical paediatric anaesthetic practice, further studies are required. These would include measurement of mitochondrial cellular activity to determine the true effect of $\mathrm{N}_{2} \mathrm{O}$ on the mitochondrial respiratory chain and $\mathrm{O}_{2}$ utilization.

\section{Acknowledgements}

The authors wish to thank Dr. J.E.S. Relton for his continuous assistance in the preparation of our manuscripts. Special thanks to Drs. Churchill, McClorie, and Khoury and the Fellows, Residents and Nurses of the Division of Urology. We also thank Medasonics Inc. for providing the Transcranial Doppler instrument used in this study.

\section{References}

1 Shapiro $H M$. Anesthesia effects upon cerebral blood flow, cerebral metabolism, and the electroencephalo- gram. In: Miller RD (Ed.). Anesthesia, 2nd ed., New York: Churchill Livingstone Inc., 1986; 1264-5.

2 Pelligrino DA, Miletich DJ, Hoffman WE, Albrecht $R F$. Nitrous oxide markedly increases cerebral cortical metabolic rate and blood flow in the goat. Anesthesiology 1984: 60; 405-12.

3 Wollman H, Alexander SC, Cohen PH et al. Cerebral circulation during general anesthesia and hyperventilation in man. Thiopental induction to nitrous oxide and d-tubocurarine. Anesthesiology 1965: 26; 329-34.

4 Theye RA, Michenfelder JD. The effect of nitrous oxide on canine cerebral metabolism. Anesthesiology 1968: 29; 1119-24.

5 Carlsson $C$, Hagerdal $M$, Siesjo BK. The effect of nitrous oxide on oxygen consumption and blood flow in the cerebral cortex of the rat. Acta Anaesthesiol Scand 1976: 2; 91-5.

6 Sakabe T, Kuramoto T, Kumagae $S$ et al. Cerebral responses to the addition of nitrous oxide to halothane in man. Br J Anaesth 1976; 48: 957-62.

7 Sakabe T, Kuramoto T, Inoue S, Takeshita H. Cerebral effects of nitrous oxide in the dog. Anesthesiology 1978; 48: 195-200.

8 Drummond JC, Scheller MS, Todd MM. The effect of nitrous oxide on cortical cerebral blood flow during anesthesia with halothane and isoflurane, with and without morphine, in the rabbit. Anesth Analg 1987; 66: 1083-9.

9 Aaslid R, Markwalder MM, Helge N. Noninvasive transcranial Doppler ultrasound recording of flow velocity in basal cerebral arteries. J Neurosurg 1982; 7: 769-74.

10 Pilato MA, Bissonnette B, Lerman J. Transcranial Doppler response of cerebral blood flow velocity to carbon dioxide in anaesthetized children. Can J Anaesth 1991; 38: 37-42.

11 Markwalder TM, Grolimund P, Seller RW, Roth F, Aaslid $R$. Dependency of blood flow velocity in the middle cerebral artery on end-tidal carbon dioxide partial pressure - a transcranial ultrasound Doppler study. J Cereb Blood Flow Met 1984; 4: 368-72.

12 Bissonnette $B$. Sessler $D I$. Passive or active inspired gas humidification increases thermal steady-state temperatures in anesthetized infants. Anesth Analg 1989; 69: 783-9.

13 Bissonnette B. Sessler DI, LaFlamme P. Passive and active inspired gas humidification in infants and children. Anesthesiology 1989; 71: 381-4.

14 Bissonnette B, Sessler DI, LaFlamme P. Temperature monitoring sites in infants and children. Anesth Analg 1989; 69: 192-6.

15 Reder RF, Dimich I, Cohen ML, Steinfeld L. Evaluating indirect blood pressure measurement techniques: a comparison of three systems in infants and children. Pediatrics 1987 ; 62 : 326-30. 
16 Badgwell JM, McLeod ME, Lerman J, Creighton $R E$. End-tidal $\mathrm{PCO}_{2}$ measurements sampled at the distal and proximal ends of the endotracheal tube in infants and children. Anesth Analg 1987; 66: 950-64.

17 Leon J, Bissonnette B. Cercbrovascular responses to carbon dioxide in children anaesthetized with halothane and isoflurane. Can J Anaesth 1991; 38: 817-25.

18 Rosenthal M, Adams MR, LaManna JC. Nitrous oxide alters oxidative metabolic activities of rat ncocortex in situ. Brain Res 1981; 213: 405-14.

19 Bissonnette B, Bickler PE, Gregory GA, Severinghaus $J W$. Effects of intracranial pressurc on brain redox balance in rabbits. Can J Anaesth 1991; 38: 654-9.

20 Todd $M M$. The effects of $\mathrm{PaCO}_{2}$ on the cerebrovascular response to nitrous oxide in the halothane-anesthetized rabbit. Ancsth Analg 1987; 66: 1090-5.

21 Vernheit J, Renou AM, Orgogozo JM, Constant P, Caille $J M$. Effects of a diazepam-fentanyl mixture on cerebral blood flow and oxygen consumption in man. $\mathrm{Br} \mathrm{J}$ Anaesth 1978; 50: 165-9.

22 Bahlman SH, Eger EI, Smith NT et al. The cardiovascular effects of nitrous oxide-halothane anesthesia in man. Anesthesiology 1971; 35: 274-85.

23 Millar RA, Warden JC, Cooperman LH, Price $H L$. Central sympathetic discharge and mean arterial pressure during halothane anaesthesia. Br J Anaesth 1969; 41: 918 28.

24 Fukunaga AF, Epstein RM. Sympathetic excitation during nitrous oxide-halothane anesthesia in the cat. Anesthesiology 1973 ; 39: 23-6.

25 Kaieda R, Todd MM, Warner DS. The effects of anesthetics and $\mathrm{PaCO}_{2}$ on the cerebrovascular, metabolic, and electroencephalographic responses to nitrous oxide in the rabbit. Anesth Analg 1989; 68: 135-43.

26 Tominaga $S$, Strandgaard S, Uemura $K$ et al. Cerebrovascular $\mathrm{CO}_{2}$ reactivity in normotensive and hypertensive man. Stroke 1976; 7: 507-10.

27 Ackerman RH, Zilkha E, Bull JW et al. The relationship of the $\mathrm{CO}_{2}$ reactivity of cerebral vessels to blood pressure and mean resting blood flow. Neurology 1973; 23: 21-6.

28 Harioka $T$, Hatano $Y$, Mori $K$, Toda $N$. Trimethaphan is a direct arterial vasodilator and an alpha-adrenoceptor antagonist. Anesth Analg 1984; 63: 290-6.

29 Olesen $J$. The effect of intracarotid epinephrine, norepinephrine, and angiotensin on the regional cerebral blood flow in man. Neurology 1972; 22: 978-87.

30 Dohi S, Naito H, Takahashi T. Age-related changes in blood pressure and duration of motor block in spinal anesthesia. Anesthesiology 1979; 50: 319-23.
31 Delleur MM, Murat I, Saint-Maurice C. Hemodynamic changes during lumbar epidural anesthesia in children. Anesthesiology 1987; 66: A426.

32 Eger EI. Anesthetic Uptake and Action. Eger EI (Ed.). Baltimore, London, Los Angeles, Sydney: Williams and Wilkins, 1981: 86-7.

33 Bissonnette $B$, Lerman J. Single breath end-tidal $\mathrm{CO}_{2}$ estimates of arterial $\mathrm{PCO}_{2}$ in infants and children. Can J Anaesth 1989; 36: 2-4. 